\title{
International Parental Child Abduction In United States Of America And India
}

\author{
Anisa Shaikh, Jayashree Khandare
}

\begin{abstract}
Intentional community concerns the issue of child parental abduction through its conventions. Total 100 countries across the world have recognized the Hague abduction convention in 2019. India is not a part of Hague Abduction Convention although Indian judiciary applying domestic personal laws and best interest principle in wrongful removal dispute in custody cases. This article gives analytical and explorative view on the issue of child abduction by parents from their habitual residence. Child abduction involves where one parent unilaterally takes the child back to his or her country in disturbed marital relationship. This article examines legal issue and problems in international parental child abduction and also throws light on International Abduction Bill. The Bill has been studied critically and analytically to suggest the recommendation. This article attempts to explain the existing statutory and judicial laws in India regarding parental abduction.
\end{abstract}

KEY WORDS: Hague convention, Parental abduction, Child custody, Habitual residence, Best interest of child, Wrongful removal, Habeas corpus.

\section{INTRODUCTION}

It is the right of every child to live peacefully in the country of habitual residence. International Child abduction is wrongfully retaining or wrongfully removing the child from his or her parents. Parental abduction is a serious issue all over the world. Parental child abduction is illegally removing the own child without other parents consent or taking away the child from habitual residence. Parental abduction means a parent living in foreign country takes the child to India without informing the other spouse. Concerned NRI parents are approaching Supreme Court to seek the direction from centre for framing law with such cases. There are no guidelines on the issue of jurisdiction and procedural aspect relating to child removal by the parents. Parents are filing cases against the other in India and other living countries on parental abductions. This results in simultaneous proceedings in two different countries. So there is need of one competent court to hear the proceedings of NRI parents over child abduction. There should be legal framework or mechanism for to help and relocate the children by amicable solution to their habitual residence. India is not recognizing parental abduction of child as a legal issue. There is no uniform policy followed by courts in India on custody matters. It is treated as personal issue between the parents. There is no international legal framework to return child from India to UK or USA.

Revised Manuscript Received on April 19, 2019.

Anisa Shaikh, Asst. Prof. Bharati Vidyapeeth Deemed University, New Law College, Pune, Maharashtra, India.(Email: shaikhag.1981@gmail.com)

Jayashree Khandare, Asst. Prof. Bharati Vidyapeeth Deemed University, New Law College, Pune, Maharashtra, India.(Email: k.jayashri1907@gmail.com)

\section{RESEARCH METHODOLOGY}

Every year cases of parental child abduction are reported all over the world like US, Australia, Germany, Canada, India, Japan and UK. In custody orders or divorce, it is very common that parent wrongfully take their child away from other a parent. US government attempts to prevent and solve international parental child abductions for the interest and safety of people. A special team from Bureau of Consular affairs of children's issues in US efforts to prevent international parental child abduction. This team has resolved 5200 abduction issues in 2018. When a parent reports wrongful detention to the officer of the team, immediately team works with foreign government for resolution, access of children. In 2018 team has returned 232 children to US and 174 cases have been resolved in other ways. US is a party to the Hague abduction Convention so it promotes principle that the Country of habitual residence of the child is the best place to resolve the issue of child abduction.

The US department encourages becoming part of the Hague abduction convention. Total 100 countries have recognized the Hague abduction convention in 2019.

What is Hague Abduction Convention (Hague Convention on Civil Aspects of International Child Abduction)?

Hague convention aims to protect rights of children from wrongful removal or retention of child by their own parents. It mainly prevents retention or removal of child from habitual residence from US and to the US. The core object is restoring the child which is existed immediately before the wrongful removal. Hague abduction convention was enforced in 1983. Till today, 100 countries are parties to this convention but India is not signatory to it. There has been enormous demand from US to Indian government to sign it. Indian government is of the view that signing of convention would lead to harassment of Indian wives who escape from disturbed relationship. The Convention supports that when child is removed from habitual residence it may not be always in the interest of the child.

Hague Convention has directed following guidelines to be followed by the countries that ratified the convention to resolve the parental child abduction cases:

- Ratified countries have to have a central authority to resolve the parental child abduction cases. Central authority is the key point of the convention for government of each country. 
- Central authority encourages amicable settlement of child abduction cases and helps to facilitate the safe return of children.

- Any application submitted to central authority is admissible in any court of partner countries without any formality.

- Convention allows to proof the habitual residence of the child so Custodial parent need not to be prove that their right to custody is violated or child has been wrongfully removed or detained by the other spouse.

- Returning the child to habitual residence does not depend upon immigration or nationality of a child.

\section{INITIATIVES OF INDIAN GOVERNMENT ON HAGUE ABDUCTION CONVENTION}

In 2017, the committee was constituted by Ministry of child development to scrutinize the issue of wrongful removal of child and to suggest model legislation for the interest of children. Large number of Indian women married in abroad, when they subject violence in their family relation they have to come back to India with

\section{FINDINGS}

Issue of parental child abduction is complex and combination of International law and domestic law. Custody issue under Hague convention is increasing as intersection between family and international law. Matters brought under the convention highlight the problem faced by the institutions while applying the laws. To workout the convention efficiently state parties must be signatory to the Hague convention. Child abduction by spouses and jurisdictional issue is not receiving much attention.

Indian government is feeling that signing the Hague convention would be against the women who are subject to abusive marriages. It is impossible for women to fight for custody in foreign countries where the child is born.

Indian Courts have already gone through its judgments on the issue of inter country and international child abduction. Some of the prominent Judgments are as follows:

Nithya Anand Raghavan v. NCT, [6] In this case writ was filed by father of the child in UK, as she was a citizen of UK. Foreign Court ordered to return the child to father as mother is illegally taken the child from father. Mother filed the case before Supreme Court of India; The Apex Court held that "the remedy of habeas corpus cannot be used for enforcement of directions given by a foreign court against a person within its jurisdiction. Indian courts should consider the interest of the child"

Kanika Goel v. State of Delhi, [7] In this case mother brought daughter to India and filed divorce case in Delhi.. Following the case of Nithya, "Supreme Court concluded that custody of female minor child with her biological mother is not unlawful. Court has applied the principle of intimate and closest concern."

\section{RESULT}

- Parents are also raising voice against center as India is not ratifying the Hague Convention.

- To work out the convention efficiently it need common jurisdiction under the treaty.
- Some measures should be adopted to protect the victim of domestic violence.

- Understanding and applying the principle of 'Best interest of child'

- Need to protect the child from unusual disturb family relation between the parents

- $\quad$ Need to accede suitable law for signing the Hague Convention on child abduction- Hague convention is aimed for prompt return of child to their habitual residence and to secure right to access to children.

- A court of habitual residence of the child is the proper place of jurisdiction to determine the custody of the child.

- There should be coordination and cooperation between courts, police and international players to resolve the matter of parental child abduction amicably. Reforms are necessary for better coordination and for better implementation of convention.

- Law Commission of India already drafted Bill on civil aspects of international child abduction, 2016 in consonance with Hague Convention. There is need to examine the provisions of the said bill.

- Legislative precedents and practices followed in the drafting bill and harmonize with Hague Convention

- Central authorities to assist the parents

- "the protection of children ( Intercountry removal and retention) bill 2016

- Law commission of India set a stage to sign Hague Convention 1980.

\section{CONCLUSION}

On international platform, India needs to resolve the global issue of parental child abduction as they are increasing day by day. Initiatives have been taken through some steps by courts. Hague Convention is a remarkable document. International parental child abduction is crime in United States of America. In US removing the child from habitual residence is criminal offence with fine and imprisonment. India needs new law to face the new challenge in Private International law. Whether India should be signatory to convention is the matter consideration. India should change according changing needs of the society. In absence of Convention Indian courts apply best interest principle for custody cases and same is followed in child abduction cases. The Law Commission of India suggested Indian government to sign Hague Convention in 2009. Thereafter Committee from Ministry of women and child development drafted Bill in 2016 on International child abduction. After Seema Kapoor v. Deepak Kapoor,[5] Law Commission of India drafted Bill in 2016, on protection on children. It is necessary to create uniform law adhering with the principles laid down by Hague abduction Convention.

\section{REFERENCES}

1 Cheshire, North, \&Fawcett, Private International Law, $4^{\text {th }}$ edition

2 Paras Diwan, Private International Law, 
3 Dr. Sai Ramani Garimella, Private International law, $2^{\text {nd }}$ edition 2018.

4 Julia A. Todd, The Hague Convention on the civil aspects of international child abduction: Are the convention's goals being achieved? Indiana Journal of Global legal studies(1995)

5 Seema Kapoor v. Deepak Kapoor, Manu/PH/1852/2017:(2018)189 PLR 246

6 Nithya Anand Raghavan v. NCT, Manu/SC/0762/ 2017

7 Kanika Goel v. State of Delhi, Manu/ SC/0760/ 2018

8 The Civil aspects of International child abduction Bill, 2016

9 Anil Malhotra, Advocate, Amicus Curaie, The law in relation to custody of children and child removal in India.

10 Annual report on International child abduction (2018) Department of State, United State of America.

11 Report of Justice Rajesh Bindal Committee to examine The Civil aspects of International child abduction Bill, 2016 and The protection of children (Inter-country Removal and Retention) Bill 2016.

12 Hague Convention on the Civil aspects of International Child Abduction.

13 Dr. Bhagyashree Deshpande and Anuradha Girme, "Research Methods Made Simple", International Journal of Innovative Technology and Exploring Engineering, 2019.

14 Dr.Ujwala Bendale and Vidya Dhere, "Right of Aged Persons to Live with Dignity: A Socio-Legal Perspective", International Journal of Innovative Technology and Exploring Engineering, 2019.

15 Sukrut Deo and Dr. Sapna Deo, "Cyber squatting: Threat to Domain Name", International Journal of Innovative Technology and Exploring Engineering, 2019.

16 Ms. Vidya Dhere and Dr.Ujwala Bendale, "Impact of Smart City on Social Relations", International Journal of Innovative Technology and Exploring Engineering, 2019.

17 Anuradha Girme and Dr. Bhagyashree Deshpande, "The Life Line of Human Beings - Right to Potable Water", International Journal of Recent Technology and Engineering, 2019.

18 Sukrut Deo and Dr. Sapna Deo, "Domain Name and its Protection in India", International Journal of Recent Technology and Engineering, 2019.

19 Sarda, M., Deshpande, B., Dharm, J., Dhere, V., Different aspects of environmental laws , International Journal of Recent Technology and Engineering, 2019

20 Sarda, M., Deshpande, B., Deo, S., Karanjkar, A comparative study on Maslow's theory and Indian Ashrama system, International Journal of Innovative Technology and Exploring Engineering ,2018

21 Sarda, M., Deshpande, B., Shringarpure, S., Smart city Use of technology and the needed labor reforms, International Journal of Innovative Technology and Exploring Engineering, 2018

22 Anwesha Pathak and A. Mishra, "Human Trafficking In India”, Journal of International Pharmaceutical Research, 2019

23 Rashmi Dubey and Ujjwala Sakhalkar, “A Critical Analysis of Rising Intolerance and Growing Polarisation: Lynching", Journal of International Pharmaceutical Research, 2019

24. Jayashree Khandare and Anisa Shaikh, "When life becomes death: a stifling story of air pollution", Journal of International Pharmaceutical Research, 2019 